\title{
Julius Bahnsen (1830-1881), filósofo do desespero heroico ${ }^{1}$
}

\section{SLOCHOWER, Harry. Julius Bahnsen, philosopher of heroic despair, 1830-} $1881^{2}$

\section{Thiago de Souza Salvio*}

O destino de Julius Bahnsen é um estranho paradoxo na história da filosofia. Embora um dos mais originais e interessantes pensadores na filosofia moderna, ele foi condenado a despender seus anos de maturidade como professor escolar da parte mais atrasada da Pomerânia, quase desconhecida, e até hoje ele é mais conhecido por um nome, pensando na (se for possível) conexão com a história do pessimismo oitocentista.

Três fatores estão envolvidos na estima de sua personalidade e filosofia e em razões de seu isolamento.

A filosofia era para Bahnsen não meramente um sistema de convicções intelectuais, construída por uma abstração analítica e preocupada com a consistência lógica. Filosofia era para ele mais uma atitude de fé, práticas éticas, atreladas às emoções elementares tendo significância vital direta. Sua própria orientação filosófica fora determinada através das fontes mais profundas e íntimas do seu ser. Esse elevado pathos moral de seu argumento, a intensidade rítmica e o caráter individual de seu idioma, são indicações arrebatadoras da extensão significante na qual sua inteira personalidade entrou na própria obra. Ideias possuíam valores pessoais para ele. Contudo, a paixão pela qual lutou por suas persuasões o envolvendo em constantes controvérsias, carregaram-no de maneira brilhante, mas ainda extremamente polêmica. Em todo lugar ele toma a posição de um lutador, ataca com rápida esgrima, agora defendendo com contra-ataques apaixonados, sempre disputante. De fato, a forma íntegra de sua apresentação recebeu sua estampa pelas controvérsias levadas contra [Eduard von] Hartmann, [Johannes] Volkelt e outros. Seu

\footnotetext{
${ }^{1}$ O presente trabalho foi realizado com apoio da Coordenação de Aperfeiçoamento de Pessoal de Nível Superior - Brasil (CAPES) - Código de Financiamento 001.

2 Tradução do artigo originalmente publicado no periódico norte-americano The Philosophical Review, Vol. 41, No. 4 (Jul., 1932), pp. 368-384. O tradutor gratifica a disponibilidade da Duke University Press.
}

* Mestrando em Filosofia na Universidade Estadual Paulista, Marília, SP. E-mail: thiagosouzasalvio@gmail.com ORCID: https://orcid.org/0000-0001-9238-5742 
caloroso e militante tom irritou diversos críticos e indubitavelmente tem sido um forte fator contribuindo frente à consideração inadequada que seu sistema recebeu.

Outra dificuldade se ofereceu pelo estilo incomum. Bahnsen possuía uma rica e bizarra imaginação, e encontrou expressão na colorida forma literária com um caleidoscópio de analogias e metáforas. Com exceção de George Santayana, não sabemos de nenhum pensador que veste suas ideias em várias figuras de discurso. Seu idioma filosófico consiste, na maioria das partes, de epítetos fortes, lampejantes e surpreendentes e envolvendo analogias. Problemas são antropomorfizados, aparecem arranjados em armadura e equipados com lanças; metáforas intensas servem para manter a tensão emocional elevada ao longo do vívido e sintomático combate. De modo que (como algumas vezes no caso de Santayana) ao menos saiba, para começar, qual é o argumento, alguém será deixado se perguntando qual ponto específico está sob discussão. Há duas dificuldades ulteriores com o estilo de Bahnsen. Ele emprega enormes latinismos e suas sentenças são muito longas e enredadas. Não tão cedo uma ideia é introduzida logo é qualificada por outra (algumas vezes colocada em parênteses), esta última em torno de alguma outra e assim vai. Uma sentença amiúde contém um valor de profundas e originais reflexões, mas o problema não é infrequentemente perdido em enpojadas discussões parentéticas.

Finalmente há um caráter único na filosofia de Bahnsen. Sua Realdialektik [Realdialética] assalta a lei de contradição e o princípio do terceiro excluído, reivindicando que a realidade é completamente contraditória. É um ataque aos longamente estabelecidos princípios lógicos emitidos por um panlogismo hegeliano nutrido longamente. A forte tentação tem sido geralmente dispensar esse desafio sem análise detida, como uma monstruosidade lógica. Combinando os aspectos contraditórios da dialética de Hegel com os elementos pessimistas do voluntarismo schopenhaueriano, o sistema de Bahnsen representa o primeiro pessimismo duradouro na história do pensamento. Se Schopenhauer, von Hartmann, [Philipp] Mainländer e outros pessimistas finalmente ofereceram 'soluções' de uma forma ou outra, Bahnsen ensina, praticamente, a inevitabilidade do sofrimento ao longo do tempo e, teoricamente, a impossibilidade da compreensão lógica da natureza. As dificuldades que ocupam a infiltração dos filósofos pessimistas têm sido poderosas o suficiente para prevenir o reconhecimento de Schopenhauer por quase quarenta anos. E Bahnsen escreveu numa época que o pessimismo de Hartmann, que chamou uma ativa fruição da vida e abandonou o futuro distante para incomodar a si mesmo com a aniquilação do mundo, ganhou ampla popularidade. 
Antes de proceder a exposição da Realdialektik, algo deveria ser dito sobre a irônica fortuna que perseguiu Julius Bahnsen em sua vida ${ }^{3}$.

O ambiente intelectual que ele despertou para a autoconsciência crítica era dominado pelas correntes dos anos quarenta [séc. XIX]. Esse período testemunhou a germinação e amadurecimento das forças que atacaram e temporariamente desmembraram a ortodoxia em sua forma política reacionária. A década viu o aparecimento dos Hallischen Jahrbücher [Anuários Hallianos], o órgão da esquerda hegeliana, e da Essência do Cristianismo de Feuerbach, um nítido apelo à religião humanista. Essa também foi a época em que Marx e Engels publicaram seu pungente manifesto político. O período foi permeado por um espírito do ceticismo na teologia, e do antagonismo diante das pálidas abstrações dos hegelianos, e por uma atitude desafiadora direcionada contra as doutrinas conservadoras vigentes dos economistas políticos. Essas foram as águas turbulentas que jogaram sobre o jovem Bahnsen. Elas se apaziguaram em seu temperamento cético-crítico e ele ficou contente em nadar nelas. Primeiro ele foi firmemente agarrado pela política revolucionária dos anos quarenta. Porém um inerentemente forte individualismo logo o levou a trasladar o acre criticismo nivelado pelos radicais sociais contra as explorações de uma classe econômica particular a um ardente protesto individualista contra a supressiva e chocante atitude de uma psicologia burguesa genérica. Incidentes pessoais e falhas acadêmicas produziram em Bahnsen o sentimento que ele era um "homem marcado", um pária, o inimigo natural da compacta maioria em suas "discrições moderadas". Ele se esforçou duramente (e, é claro, em vão) para revelar as táticas desonestas que ele encontrou na vida acadêmica, por atravessar as muitas intrigas e a hipocrisia lisa daqueles discretos "cavalheiros e eruditos" que sorriam afavelmente enquanto atacam, e estimulavam uma atitude bem disposta enquanto destruíam. Ele tinha um senso incomum para a sinceridade inequívoca. E embora ele continuamente se sujeitasse ao ostracismo social e econômico de um ambiente no qual tal transparente honestidade era considerada "não bem aceita", ele não desencorajava. "E se meus amigos se recusarem a me ouvir, então as paredes vão me ouvir, ou as pedras nos campos e as árvores nas florestas".

Julius Bahnsen nasceu em 30 de Março de 1830 em Tondern-Schleswig numa família frísia e ancestral da Saxônia Antiga. A mãe morreu logo após o gerar, abandonou a criança a uma solitária e entristecida infância. Quando ele cresceu, foi mandado para o ginásio, e lá ele chegou a ter contato com as correntes críticas predominantes. O ano de

\footnotetext{
${ }^{3}$ Compare a introdução simpática de Rudolf Louis na edição da autobiografia póstuma de Bahnsen Wie ich Wurde Was ich Ward (München \& Leipzig, 1905), citado aqui como Autobiographie. A autobiografia foi reeditada por A. Ruest e reimpressa por A. Barth, Leipzig, em conexão com a celebração do centenário do nascimento de Bahnsen, dois anos atrás.
} 
1847 ele destinou a tempo de acordar para o pensamento independente. A ideia que o homem é apenas um "nada autoconsciente" então emergiu de si mesma para ele ${ }^{4}$. Na virada de 1848 ele entrou na universidade de Kiel, mas a guerra de 1848-1850, que envolveu Schleswig, interrompeu seus estudos. Ele se alistou e serviu por dezoito meses ${ }^{5}$.

Os dois anos seguintes (1851-53) ele dispendeu na universidade de Tübingen. Ele originalmente tentou entrar na profissão teológica, mas a leitura de Feuerbach e [Arnold] Ruge e as primeiras inclinações em direção a um niilismo antiteológico logo o conduziram ao abandono do projeto, e ao invés ele fez da filosofia seu principal estudo em Tübingen. Lá [Theodor] Vischer, o renomado filósofo e docente de estética, exerceu a maior influência pessoal sobre ele; porém foi [Jakob] Reiff quem o introduziu aos problemas gerais da filosofia, e foi através dele que Bahnsen pela primeira vez ouviu falar de Schopenhauer ${ }^{6}$.

Durante seus quatro semestres em Tünbingen, Bahnsen não compareceu a nenhuma aula de I. H. Fichte - apesar de ser o decano com o qual Bahnsen colaria grau - pela razão que ele sentiu repulsa do idealismo teísta tendencioso. $O$ tempo e, novamente, tal honestidade intelectual, tal desconsideração pela 'diplomacia', se tornaram a fonte de reveses acadêmicos. Ele mesmo escolheu o tema de sua dissertação, que foi "Uma tentativa de analisar geneticamente, segundo os pressupostos da psicologia científica as doutrinas a respeito das categorias estéticas básicas"7. O comentário de Vischer sobre isso foi que embora o trabalho falhe em fundamentar a ideia de beleza sobre um novo princípio, ele descobre, por outro lado, uma riqueza de intuições profundas e fecundas e uma maturidade assombrosa de pensamento para um homem de vinte e três anos.

Por toda sua vida Bahnsen se considerou um discípulo de Schopenhauer. No ano de 1856, ele chamou-o de mestre. "Fui consciente de que não veria apenas o gênio das ideias, mas também o caráter da mais genuína sublimidade... Senti-me... transportado em uma nova existência. Francisco de Assis e outros heróis do ascetismo se tornaram meus ideais” 8. Quatorze meses depois ele viu Schopenhauer novamente. Nesse ínterim, ele leu e estudou "cada linha" do reverenciado professor, e Schopenhauer honrou seu novo assecla o classificando junto ao "apóstolo" Frauenstädt.

\footnotetext{
${ }^{4}$ De sua leitura de Trendelenburg durante os estudos universitários ele se lembrou de uma frase picante: há mentes negativas cujo aparato pensante sempre tende a conclusões negativas. Bahnsen acrescenta que na sua primeira juventude em diante ele escutou com um ouvido receptivo a tudo que lhe serviu a dissolução crítica Autobiographie, p. 106.

${ }^{5}$ É interessante notar que os três dirigentes pessimistas schopenhauerianos, Hartmann, Mainländer e Bahnsen, voluntariamente se alistaram no exército e todos por alguma razão:para disciplinar e fortalecer o corpo e o espírito - a favor da batalha pelo Nirvana!

${ }^{6}$ O System der Willensbestimmung [Sistema da Determinação da Vontade] de Reiff apresenta um voluntarismo metafísico sem implicações pessimistas.

${ }^{7} \mathrm{O}$ trabalho parece estar perdido.

${ }^{8}$ Autobiographie, p. 47.
} 
A autobiografia de Bahnsen contém no título, 'De uma batalha perdida' (" Auf verlorenem Posten"), e começa: "Quanto mais eu vivo, mais sinto que a mais simples fórmula para a constância do meu destino é: de uma vista perdida". Ele nos dirá de como foi na vida e no pensamento pareceu constantemente deslocado. Quando o materialismo dos anos cinquenta ficou em voga, ele há muito tempo já o havia superado; e quando nos anos sessenta Schopenhauer se tornou moda, o pessimismo diplomático de Hartmann o destituiu do merecido reconhecimento. A era que aclamava o pessimismo nada saberia sobre quem o representasse clara e intransigentemente. Essa condição era parcialmente responsável pela falha em obter uma cátedra acadêmica; e, a despeito de todos os esforços, ele foi compelido a desperdiçar seus melhores anos ensinando disciplinas elementares em uma pequena cidade provinciana. Uma personalidade criativa, original e dinâmica era assim forçada a gastar seu exuberante entusiasmo sua espantosa energia e vitalidade, nas balbúrdias mesquinhas da política provincial e na disciplina de jovens pomeranos obtusos.

Acrescente-se a isso, que Bahnsen sofreu em sua vida particular de solidão e de um casamento imprudente. Era uma de suas mais profundas aspirações para estabelecer um nicho familiar pacífico e harmonioso. Esse desejo não era para ser completado. Seu primeiro casamento foi com uma mulher conveniente e inteligente, mas a morte a tomou dele um ano depois da união. Um segundo casamento provou em cada aspecto um triste desapontamento. Em sete de dezembro de 1881, Julius Bahnsen morreu, apenas aos 51 anos de idade, pelo que a princípio pareceu ser um leve caso de difteria. Ele sumarizou sua vida em um epitáfio escolhido por si: Vita mea irritus labor [minha vida de trabalho em vão].

II.

A ideia conducente do sitema de Bahnsen, a chave para sua metafisica, ética e estética, é o princípio da 'Realdialektik'. Sua tese fundamental afirma que o princípio de contradição é predicado da existência, onde existência compreende ambos os âmbitos do conhecimento e da natureza. O termo 'Realdialektik'é empregado em consciente oposição a dialética 'verbal' de Hegel. "Dialektik" aqui significa contradição exceto a possibilidade de reconciliação na 'síntese'. 'Real' indica que essa dialética ou contradição tem direta e completa aplicabilidade à natureza ou realidade. A dialética conciliatória de Hegel, Bahnsen chama de, apenas verbal. Essa não pode ter relevância para uma existência a essência que não é harmoniosa mas antitética. Kant distinguiu entre contradições lógicas e

\footnotetext{
${ }^{9}$ A exposição mais detalhada desse conceito encontramos na obra principal de Bahnsen, Der Widerspruch im Wissen und Wesen der Welt, Princip und Einzelbewährung [A contradição no saber e essência do mundo, princípio e prova singular], 2 Bande., Leipzig, 1882. Citado aqui como Realdialektik.
} 
oposições existenciais, e mostrou que elas devem existir lado a lado; ele também considerou as antinomias como devido à natureza específica do nosso pensamento e não como estando em verdade nos objetos. As reivindicações desafiadoras e impressionantes da Realdialektik são que as contradições embalam ambos o espírito da fenomenologia do espírito e aquele da natureza, e que cada elemento individual porta propriedades opostas dentro de si mesmo; em outras palavras, que todas as coisas na natureza são permeadas por antinomias, rachadas e divididas contra si mesma ${ }^{10}$.

Embora todos os escritos de Bahnsen sejam mais ou menos preocupados com a clarificação dessa ideia, em nenhum lugar uma prova rigorosa é oferecida. Ele aponta a dificuldade na tentativa de uma exposição lógica e justificação de um princípio antilógico. Além disso, a fonte da dialética real é a intuição de que a natureza do mundo oferece um enigma que precisamos nos desesperar para resolver por meio de categorias lógicas. $\mathrm{E}$ Bahnsen recorre às nossas faculdades intuitivas para preencher a lacuna entre o mundo da vontade e o mundo do conhecimento. Porém, embora faltem razões irrefutáveis, ainda podemos nos convencer de fatos inegáveis ${ }^{11}$. Infelizmente, os fatos ilustrativos aduzidos são poucos, dispersos e nem sempre relevantes. Além disso, ele não distingue claramente entre contradições lógicas, antinomias metafísicas e oposições existenciais; e embora seu termo 'Realdialektik' supõe incluir todos eles, as ilustrações oferecidas aplicam-se primariamente somente ao último.

O fenômeno realdialético que Bahnsen enfatiza acima de tudo é o da consciência de si. Sua forma mais simples já revela a união de opostos, sujeito e objeto. Enquanto o ego deseja, é ao mesmo tempo o produto da vontade; continuamente passa por desenvolvimento e, contudo, sempre mantém sua identidade; quer e sabe; foge das garras do pensamento e, no entanto, só ele é capaz de consciência. O que para Schopenhauer foi um "milagre" (que o eu é ambos: sujeito e objeto) a Realdialektik chama de antinomia mais fundamental da vida. Nos escritos de Bahnsen, encontramos referências a outros fenômenos dialéticos reais em vários campos, variando da epistemologia e física à psicologia e metafísica. Na epistemologia, temos a situação paradoxal de que um objeto, para ser conhecido, deve estar além da esfera do conhecimento e, todavia, deve estar nela ao mesmo tempo. O jogo das forças físicas é baseado na lei de ação e reação, e revela que nenhuma força pode existir a menos que seja resistida por outra força. Exemplos ulteriores de oposições físicas inseparáveis são os fenômenos de polaridade, de gravidade centrípeta e centrífuga e de fluxo e refluxo. A vida e o crescimento biológicos são condicionados pela constante morte e descamação dos tecidos. Toda ética genuína combina auto-afirmação e auto-negação. Somos lembrados do ditado legal: summa jus, summa injuria [suma justiça, suma injustiça]. A possibilidade de progresso pressupõe a inadequação de uma determinada situação existente. Bahnsen aponta para o fato psicológico de que nosso

\footnotetext{
${ }^{10} 8$ Realdialektik, Vol. I, pp. 62, I 55; Vol. II, pp. 452 ff.

${ }^{11}$ Realdialektik, Vol. I, pp. 8, 97, 26, 45.
} 
cérebro funciona momentaneamente melhor em períodos de exaustão mental e chama a atenção para o proverbial desejo de conhecimento, um desejo que aumenta a cada aquisição de conhecimento. Metafisicamente, somos confrontados com orientações complementares semelhantes. Quanto mais insistimos na mudança e na diferença, mas implicar-se-á numa certa persistência e identidade atuais. A causalidade (como mostrou Kant) repousa sobre uma oposição unida: a causa deve conter o efeito e, no entanto, ser diferente dela. Da mesma forma, o mundo contém acaso e necessidade, matéria e mente, lei e contingência, etc ${ }^{12}$.

A base para a natureza contraditória de toda a existência Bahnsen coloca na Vontade. A tese que uma vontade cega faz para a irracionalidade da existência já havia sido mantida por Schopenhauer. Mas sua introdução das Ideias Platônicas e o poder que ele conferiu ao intelecto trouxeram alguma ordem e razão a um regime voluntário. A vontade de Bahnsen, por outro lado, é e permanece intransigentemente irracional, não admitindo um monitor lógico para interferir em suas atividades. Todo o reino da existência é a manifestação exclusiva de seus caprichos. Agora, a vontade também está sujeita ao princípio universal da Realdialektik, e isso significa que também é ontologicamente cindida e autodividida. Assim, em nenhum momento a vontade aparecerá como uma entidade singular ou unificada; sua "autodivisão é uma parte ante e uma parte pós igualmente eterna". Em outras palavras, as contradições estão presentes na vontade pura, antes e depois de seu conteúdo autocontraditório. Uma dialética contraditória é assim colocada no coração do processo cósmico. Bahnsen considera essa dialética como uma característica tanto do mundo da existência quanto do mundo da essência, como o "conteúdo interno absoluto do ser". Se Hartmann casou sua vontade vazia e ansiosa com a ideia, dotando assim a vontade com um conteúdo lógico, Bahnsen, impedindo essa ligação e insistindo na independência suprema da vontade, aponta para o elemento motivador de sua própria natureza como o conteúdo único e adequado da vontade. Na falta de entranhas lógicas, a vontade expressa sua verdadeira idiossincrasia realdialética (já familiarizada por Schopenhauer), na medida em que encontra a paz somente através da inquietação de um esforço que continua eternamente apesar de todas as falhas ${ }^{13}$. A vontade quer (repouso) o que não quer (querer). Amaldiçoado com dissensão, ela constantemente se dilacera ao estender-se para sempre de todos os lugares aqui e agora para alguns distantes ali e depois.

A colisão metafísica entre as presas da vontade realdialética, pela qual o mundo objetivo da realidade é constituído, também aparece nos conflitos psicológicos entre

12 Zur Philosophie der Geschichte [Contribuição para a filosofia da história], Berlin, 1872, pp. $27,43$. Doravante citado como Philosophiegeschichte. Realdialektik, Vol. I, pp. 37, 50, 93, II3; Vol. II, pp. 7 ff., 20 , 59, 62, 65, 82, 84, I94, 464 ff., e passim.

131 Realdialektik, Vol. I, pp. 46, 5I, 245, 29I; Philosophiegeschichte, p. 2. 
desejos e motivos divergentes dentro da mesma aparência individual orgânica ${ }^{14}$. Surge aí o problema da relação da vontade universal e suas manifestações particulares. Através disso, Bahnsen investe contra qualquer forma de panteísmo e defende firmemente um pluralismo individualista. Ele rejeita a epistemologia de Schopenhauer e sustenta que espaço, tempo e causalidade, mudança e devir e, consequentemente, a existência individual, não são reais isolados, mas é a única realidade. Somente se considerarmos o tempo e o espaço reais, podemos explicar a vontade (um processo temporal) e a existência da pluralidade. Só existem vontades individuais (Bahnsen as chama Henaden [unidades], ou átomos de vontades supremas). Eles têm status ontológico eterno e, em consonância com sua natureza realdialética, estão sempre em guerra um com o outro. Mas enquanto ele mantém a substancialidade das vontades individuais, Bahnsen (fiel ao seu princípio de polaridade) ao mesmo tempo fala de uma vontade universal. A relação entre os dois ele não deixa claro. Às vezes, ele parece considerar as Henaden, outras vezes a vontade, como a realidade primária. Ou seja, ele desvia entre um pluralismo e um monismo ${ }^{15}$.

III.

Essa metafísica parece implicar um pessimismo varredor e sem mitigação. Um mundo cuja essência é uma vontade cega e dividida, que se manifesta em indivíduos irracionais e autodestrutivos, tendo uma eterna subsistência ontológica, não deixa espaço para um raio de razão, não contém momentos de descanso, não oferece nenhum caminho de fuga e nenhuma possibilidade de salvação. Para começar, temos todos os aspectos temerosos do "pior dos mundos" de Schopenhauer. Devido à vontade, existe a mesma maldição de atividade inquieta e desejo sem descanso e satisfação possíveis, a mesma luta e negação eterna aos nossos queridos anseios. Mas o pessimismo de Bahnsen vai ainda mais longe. A vontade de Schopenhauer, embora cega, age em parte como se fosse inteligente. Aparece em várias objetivações ordenadas e, no último evento, produz uma prole inteligente. $\mathrm{O}$ mundo de Bahnsen não conhece tal poder que possa se revoltar contra o reino errático da vontade e trazer paz aos súditos que sofrem. Aqui, o governante irracional é e permanece incomparável. Além disso, devido ao seu caráter realdialético, a

\footnotetext{
${ }^{14} \mathrm{O}$ Tristan de Gottfried von Strassburg é citado como a experiência de tal autodiscórdia dilacerante em seu imo: "Wider sinem willen kriegete er/ er gerte wider siner ger/ er wolte dar und wolte dan" [No mencionado romance (versos escritos em alto alemão médio) encontramos na edição de Karl Marold (1906, p. 166), a referência citada terminando na linha 11.755, e o verso do meio é destacado pela estrofe número 35 (para consulta mais precisa, confira Der Minnetrank [A gruta da mina], 295, 33-35, 11.753-11.755). Seguindo as numerações, podemos cotejar com a tradução de Krohn do moderno alemão: "Er wollte gegen seine willen/ wünschte gegen seinem wünsch/ Er wollte zu ihr und wollte fort”. Para destarte se aproximar da nossa: Ele queria contra sua vontade/ desejou contra seu desejo/ Ele queria ir ter com ela e queria partir [N. T ]. ${ }^{15}$ Realdialektik, Vol. II, pp. 70, 80, 102 ff., 169, 429.
} 
vontade deseja a ambos o querer e o não querer, e essa oposição inseparável de sua natureza previne de se negar ou afirmar a si mesma radical e efetivamente. "A conclusão da Realdialektik é: 'Não basta' tanto para a completa aniquilação quanto para a total satisfação. O filho de Gaia nasce entre o céu e o inferno, agora pronto para acampar com as criaturas reluzentes que caem na escuridão ctônica, agora pronto para flutuar nas alturas do esplendor." É essa posição entre dois mundos, pairando e oscilando entre dois extremos e nunca alcançando um equilíbrio, que contribui para a eterna desarmonia humana. Bahnsen traduz a expressão metafísica de Platão, de que somos tanto quanto não somos, em ética. "Participamos" suficientemente do domínio dos valores para ter um grande anseio por ele, e esse domínio está tão metafisicamente tão distante de nós que nossos anseios permanecem eternamente desagradáveis. A esfera de valores e a esfera da existência são necessariamente distintas, embora sempre impliquem e apontem uma para a outra. A tragédia do homem consiste precisamente no fato de seu mundo não ser claramente monista nem nitidamente dualista. Essa fórmula de dois gumes sela um pessimismo consistente. Nega a possibilidade de uma afirmação de todo o coração ou negação da vontade de viver, priva o homem da esperança de encontrar a felicidade em uma vida ativa ou em paz no estado do Nirvana, o obriga a uma eternidade desconsolada de Assuero $^{16}$. Para o indivíduo em particular, esse dualismo significa tragédia inevitável. Pois a tragédia decorre do desejo de se fazer duas coisas, sendo capaz de fazer apenas uma ${ }^{17}$. A vontade de Bahnsen não conhece tese e síntese, mas apenas uma antítese, nenhuma "ideia" para planejar um processo evolutivo intencional. Ele conhece apenas uma eterna autocisão arrastando a si mesma numa tortura sem fim ${ }^{18}$ ("In ewiger Selbstentzweiung zu endloser Qual an sich selber zerrend' ${ }^{19}$.

\footnotetext{
${ }^{16} \mathrm{O}$ nome aparece no Antigo Testamento da Bíblia, aqui parece se referir à figura mítica do "judeu errante" [N. T].

17 Bahnsen cita Rüdiger na Niebelungenlied como expressando a "Urwort" [palavra primordial] de toda tragédia: "Swelhes ich nu lâze unt das ander began/so hân ich boesliche un vil uebel getan:/ lâz aber ich sie beide, mich schendet elliu diet”. [ Na edição de Karl Simrock (1868, p. 704-705), encontramos na tradução do alto médio alemão ao lado (a citação original termina em “(...) ellieu diet”/ "mich alle Welt"; porém aqui translistera-se a estrofe completa): "Welches ich nun lasse das Andre zu begehn/ So ist doch immer böslich und arg von mir geschen/ Und wenn ich Beides lasse, so schilt mich alle Welt/ Nun möge mich erleuchten Der mich dem Leben gestellt" (2091-2265). Portanto a partir dessa última traduzir-se-á: "Que eu deixo agora a outrem para se comprometer/ Por isso é sempre malicioso e malfeito sucedido por mim/ E se eu deixar os dois, o mundo inteiro vai repreender-me/ Agora posso ser iluminado por aquele que me deu a vida" [N. T]

${ }^{18}$ No original lê-se: "It knows only an endless self-masochism and torture" (...), todavia, não contempla a sentença traduzida do alemão [N. T].

19 Das Tragische als Weltgesetz [O trágico como lei do mundo], Lauenburg i. P., i877, reimpresso por A. Barth, Leipzig, I930. Realdialektik, Vol. I, pp. I77, 2II f., 9; Vol. II, pp. 2II f., 359 f., 401, 328, 482, 236; Pessimistenbrevier [Breviário pessimista] (anônimo), Berlin, 2 Aufl., 1881, p. 101 e passim; Autobiographie, pp. I74-5; Philosophiegeschichte, p. 14.
} 
Entre os poderes atribuídos ao homem pela tradição clássica em filosofia está a possibilidade de compreender os processos da natureza por meio do pensamento. Se o homem falha em outras atividades (práticas), ele sempre pode obter paz e manter sua dignidade por meio dessa visão intelectual. A Realdialektik também desafia essa afirmação. Como a estrutura da existência é dialética, os cânones da lógica formal não podem ser adequados para uma compreensão conceitual dela ${ }^{20}$. A dialética de Hegel era um método para descrever apenas o desenvolvimento da ideia lógica, e não a existência empírica. Além disso, essa metafísica tentou uma violenta construção da realidade por meio de conceitos fantasmagóricos e, na tentativa de estabelecer uma mesma lei para o ser e o pensamento, ignorou as limitações do primeiro em seu culto cego a uma ordem panlogista infalível. Na verdade, contudo, a existência é caracterizada por contradições e, como as categorias lógicas necessariamente a exclui, a lógica está sempre destinada ao fracasso no intento de expressar a natureza do ser. Segue-se ainda que o pensamento está em contradição consigo mesmo. Em sua busca pela verdade, deve - se é para formular a natureza de uma realidade antinômica - tornar-se falso à sua própria lei. O ajuste do pensamento lógico à existência antilógica é impossível. Dessa maneira, Bahnsen interdita o templo que até então fora mantido aberto como o último refúgio do "culto de um homem livre" 21 .

Uma metafísica realdialética é necessariamente comprometida com uma filosofia cética da história. Num tratado inicial e especial, Bahnsen organiza argumentos indutivos e dedutivos contra o otimismo evolutivo e teleológico de Hegel e Hartmann ${ }^{22}$.

Como vimos, a única realidade no mundo de Bahnsen é uma pluralidade de vontades individuais. Mas, diferente das mônadas de Leibniz, essas Henaden não são desprovidas de janelas, e seu curso pré-estabelecido não é aquela da harmonia, mas da discórdia, pois estão constante e abertamente em guerra entre si e dentro de si. Esse eterno masoquismo inter e intra-individual é a única matéria de discussão de um processo circular do mundo, constitui o único "progresso" que existe. Em locuções fortes e marcantes, Bahnsen ataca o historiador panlogista e pergunta como a 'ideia' de Hegel ou o inconsciente onisciente de Hartmann podem ser reconciliados com os 'erros' históricos, como o caput mortuum [restos mortais] da antiga Índia e a extinção de raças. "Devemos considerá-los reservatórios do espírito do mundo, que este último usa como alojamento temporário, antes de entrar em seu quartel-general com todas as tropas?" E Bahnsen continua apontando a vantagem metodológica de seu próprio princípio. Com base em seu caráter de Janus, a Realdialektik, pode explicar tanto o propósito quanto o acaso na história. Por outro lado, o panlogismo de Hegel, se estritamente interpretado, não oferece

\footnotetext{
${ }^{20}$ A alegação não é que o princípio da Realdialektik se aplique à lógica. A intocabilidade da relação lógica dos conceitos entre si permanece. Cf. Realdialektik, vol. I, pp. 63 f., 203.

${ }^{21}$ Realdialektik, Vol. I, pp. 198, 13, 202-3.

22 Zur Philosophie der Geschichte, op. cit.
} 
"asilo para vagabundos sem lei (pecadores contra a ordem lógica), nenhum parque de diversões gratuito é concedido pelo mestre do mundo em seu bom humor a cada um desses duendes, onde eles podem ter o privilégio de se movimentar e se divertir de uma maneira não relacionada ao propósito racional do mundo - até que chegasse o dia e a vassoura do mestre da corte que os varreria ao santuário”. O protesto de Bahnsen é contra uma leitura forçada do plano e da lógica em eventos históricos. O caminho da história não é delimitado por categorias lógicas, mas manchado com coágulos de sangue derramados pela espada realdialética. A história, também, a despeito de Hegel e Marx, não poder ir além da antítese. O túmulo de todo período do mundo é o berço certo de um novo sepulcro ${ }^{23}$.

$\mathrm{O}$ pessimismo de Bahnsen abrange a existência e o conhecimento, o mundo e o indivíduo. O eixo do mundo é a dor e é girado pela energia inexaurível emergido pelas 'Mães' obscuras do submundo ${ }^{24}$. Sua escatologia não oferece escapatória das torturas infligidas a nós por outros e por nós mesmos. Nem o suicídio pode nos libertar, pois após a morte o indivíduo se torna o que era antes: um ato invisível da vontade, que exige apenas a ocasião de um novo impulso para se tornar visível novamente. A vida é, assim, um doloroso perpetuum mobile [perpétuo motor]. Por todo o mundo, persegue uma discórdia interminável, pois a vontade carrega as raízes da insatisfação em seu peito por toda a eternidade. Teoricamente, também, o caminho é barrado; pois todo o nosso conhecimento gira em um círculo de contradições. E para o consolo do espinozista que a paz pode ser conquistada pela realização da necessidade do processo mundial, Bahnsen retruca apaixonadamente: "A incapacidade de se resignar à ordem necessária também é uma necessidade e a dor é, por isso, não menos importante! ” O pessimismo de Bahnsen parece absoluto ${ }^{25}$.

IV.

Curiosamente, no entanto, é o próprio princípio da Realdialektik, em virtude de sua insistência da natureza polar de toda a existência, compromete Bahnsen a admitir a existência de alguma razão e de alguns valores no universo. Ele está ciente da consideração lógica de que o universo não pode ser condenado como um todo, que a ausência de um padrão objetivo impossibilita um pessimismo absoluto ou universal. Para começar, ele faz a admissão puramente formal de que existe certa regularidade, nomeadamente a regularidade da contradição, na medida em que a vontade contraditória retém sua identidade $^{26}$. Além disso, ele percebe que o totalmente contraditório é absurdo ou

\footnotetext{
${ }^{23}$ Geschichtsphilosophie, pp. 38, 45, $70 \mathrm{ff} ., 84$

${ }^{24}$ Das Tragische als Weltgesetz, op. cit., pp. $52 \mathrm{f}$.

${ }^{25}$ Realdialektik, Vol. II, pp. 494, 425, 78.

${ }^{26}$ Pessimistenbrevier, p. 247; Philosophiegeschichte, p. 67.
} 
impensável, e indica que, em certa extensão a experiência deve ser considerada como tendo ordem. Ele descobre que dentro do objeto individual cindido cada metade segue um curso lógico e que a única contradição que existe é aquela entre as duas metades. É essa "lógica parcial" que explica a adaptabilidade limitada existente do pensamento à realidade. Ele também concede que, em algumas instâncias, a dialética da natureza permite que algum bem adentre em um mundo mau ${ }^{27}$.

Bahnsen fala do amor inato da vida do homem. Faz-se sentir mesmo nas tristes consequências da Realdiatlektik. Pelo menos em um exemplo, Bahnsen aponta para uma avenida definida de fuga -a saber, através do humor. No humor, o intelecto é liberado pela primeira vez do poder sinistro da vontade; e com um grande esforço, ele se eleva para a esfera do puro espírito - e ri. Não é o riso de Demócrito nascido de uma alegre aceitação do inevitável, mas o riso de um espírito realdialético que se apoia em seus próprios ombros, observando a profunda tragédia abaixo e, por um momento, livre para observá-la. Aqui Bahnsen, talvez sem querer, presta homenagem a Hegel. O Weltgeist [espírito do mundo] aparece como a luz do farol, que em momentos é capaz de penetrar na escuridão da vontade. Porém é mais pelas implicações práticas que Bahnsen extrai de sua filosofia que seu pessimismo perde algo de seu aguilhão. Embora ele não admita a possibilidade de uma solução radical, ele nos lembra de que o homem ainda pode salvar sua dignidade por uma aceitação heroica e estoica do inescapável. "Ich denk' als Männer tragen wir auch dies [penso que como homens também carregamos isso]..." Ele condena como fúteis todas as fugas propostas por Schopenhauer e se volta, em particular, contra os idealistas românticos que persistem em suspirar e ansiar por objetos que estão além de seu alcance. Isso só leva a um sentimentalismo fútil e a uma Weltschmerz [dor do mundo] enervante. E em contraste com todos os pessimismos anteriores (exceto a vigorosa marca oferecida por Hartmann), a Realdialektik insta o abandono do quietismo. O homem acha que as coisas não são como ele gostaria que fossem e, embora ele não esteja em posição de alterar a situação, ele tem, não obstante, um desejo de fazer algo a respeito. Aqui reside a justificativa prática e dialética real de uma vida ativa. "O que em todo o mundo", afirma Bahnsen, "coragem tem a ver com esperança?"28.

Afirmando enfaticamente a vontade de viver - para ter certeza, não com a alegria dionisíaca de Nietzsche na existência, mas porque ele acredita que a negação da vontade é uma impossibilidade - Bahnsen, o "disevangelista", é encontrado no final de sua estrada batalhando pela mesma bandeira que o cantor ébrio de vida pelo qual o além-do-homem

\footnotetext{
${ }^{27}$ Realdialektik, Vol. I, pp. 167-8, 194, 356, I5I-2; Vol. II, pp. ii, ix, 84, 482; Pessimistenbrevier, pp. 247, I99. No prefácio ao segundo volume da Realdialektik Bahnsen, professa apenas um ceticismo em relação a encontrar categorias lógicas adequadas para uma descrição dos fenômenos naturais.

${ }^{28}$ A discussão de Bahnsen sobre o humor é encontrada em Das Tragische als Weltgesetz, op. cit.; Realdialektik, Vol. I, pp. 2ii, 3; Autobiographie, p. 180.
} 
[ ̈̈bermensch] jurou, mas com a diferença de que Bahnsen está lutando por uma bandeira que ele sabe que está fadada à eterna derrota.

Apesar de Bahnsen se considerar um discípulo de Schopenhauer, na verdade (como já indicamos), poucas tábuas schopenhauerianas aparecem na Realdialektik. Um realismo transcendental em relação ao tempo, espaço e a causalidade e um pluralismo substituem o subjetivismo de Schopenhauer na epistemologia e em seu panteísmo. As objetivações teleológicas da vontade de Schopenhauer, as ideias platônicas e, finalmente, as soluções através da arte, contemplação, amor e ascetismo, que embotaram a borda do pessimismo de Schopenhauer, são todas rejeitadas por Bahnsen ${ }^{29}$.

Ainda existem laços mais frouxos entre Bahnsen e Eduard von Hartmann. Para ser preciso, ambos os pensadores tentaram uma amalgamação das filosofias de Schopenhauer e Hegel; entretanto, Bahnsen aceita ambos o que Hartmann rejeita (irracionalismo de Schopenhauer e a dialética da "negatividade" de Hegel) e rejeita em ambos os que Hartmann aceita (os elementos lógicos) ${ }^{30}$.

Assim, fica claro que Bahnsen representa o antípoda direto de Hegel. A Realdialektik se opõe à dialética verbal de Hegel. O panlogismo é substituído por uma dupla legislatura por ser e pensar. Para Hegel, o ilógico e o princípio da contradição são apenas momentos de transição do lógico (tese) para o lógico (síntese). Para Bahnsen, a lógica serve apenas como um momento de transição do alógico para o ilógico ${ }^{31}$. Finalmente, Bahnsen repele o evolucionismo, o panteísmo e o otimismo de Hegel.

Ambas a maneira e a matéria da filosofia de Bahnsen convidam críticas. Mas em que termos essa crítica pode ser declarada? O objetivo do princípio realdialético é revelar a impotência do método lógico. O próprio Bahnsen recorre à analogia e metáfora, convidando o leitor a usar sua imaginação e confiar em sua intuição. E supõe que possa ser logicamente demonstrado que existem inconsistências no sistema de Bahnsen? A

\footnotetext{
${ }^{29}$ Realdialektik, vol. II, pp. 105, 169, 429 e passim. Bahnsen está de acordo com Schopenhauer ao afirmar a primazia da vontade e ao considerar o intelecto apenas como sua eflorescência. Ele também sustenta a ideia de Schopenhauer de que o caráter é imutável e que o homem é determinado in operari [no agir], mas livre in esse [no ser]. Cf. Realdialektik, vol. II, "Moirologischer Anhang" [Apêndice Moirológico]. A luta pela existência na natureza foi para Schopenhauer também uma revelação da "Discórdia da vontade consigo mesma” [Entzweiung mit sich selber]. Cf. W I. p. I75.

30 Bahnsen e Hartmann, também diametralmente opostos em caráter bem como temperamento, permaneceram ao mesmo tempo em amistoso pé de igualdade. Porém, contatos pessoais adicionais, todavia (em Driburg, em 1872 e 1873) trouxeram mais diferenças do que acordos. Que a destreza e o virtuosismo de Hartmann na apresentação das ideias (principalmente de outras) devam ser altamente avaliados, enquanto suas intuições originais deveriam ser ignoradas, era uma fonte de amargura para o homem mais velho. Cf. R. Louis em Autobiographie.

${ }^{31}$ Originalmente, segundo Bahnsen, o Ens [ente] metafísico não tinha nada a ver com a razão, era alógico. Mas desde que o homem adquiriu "a norma de um esquema lógico (como um produto secundário da vontade)", o alógico tinha que aparecer, quando medido em seus termos, como antilógico. Cf. Realdialektik, vol. I p. 203.
} 
Realdialektik poderia muito bem receber tal prova como uma ilustração de seu próprio princípio; seria (como dito) agir no espírito da Realdialektik para desafiar suas alegações. E se o espaço for permitido, poderá ser feita uma tentativa de elaborar as seguintes dificuldades, que aqui só podem ser afirmadas. Como reconciliar a substancialidade das Henaden com a da vontade universal? Como explicar a origem e o desenvolvimento da consciência e de uma "lógica parcial" em um mundo governado desde o início por uma vontade alógica? A Realdialektik, como foi apontada anteriormente, falha em estabelecer distinções claras entre contradições, antinomias e oposições, e negligencia mostrar os respectivos campos aos quais cada um se aplica. No que diz respeito às contradições, podese dizer que elas podem existir apenas no domínio da lógica formal e que não faz sentido falar de coisas ou objetos como tais sendo contraditórios. O desafio parece, no entanto, não ser direcionado contra o princípio da contradição, mas principalmente contra a aplicabilidade do princípio do terceiro excluído à existência. A afirmação mais persistente de Bahnsen é que a natureza da existência atual é polar, que objetos e eventos conflitam um com o outro e (desde que possuem propriedades opostas) também consigo mesmos, e essa existência escapa, portanto, de ser apreendida pela lógica formal. Ele levanta aqui uma importante questão lógica que não podemos abordar neste ponto. Porém deve-se notar que, embora essa argumentação seja concedida, ela não compromete o seu pessimismo. Pois apesar da tentativa schopenhaueriana de mostrar um vínculo entre irracionalismo e pessimismo, pode-se questionar se a felicidade é necessariamente condicionada pelo conhecimento lógico. E embora possa ser verdade que todo evento no universo é condicionado por uma força que se opõe a ele, permanece o fato de que ações, movimentos e afins ('progresso' em certo sentido) existem. Embora possamos não estar chegando a lugar algum, alguma satisfação ainda pode ser derivada do esforço em si mesmo. Entrementes, por mais válidas que sejam as críticas aplanadas contra Bahnsen, deve-se acautelar ao seguir os passos de Hartmann e dispensá-lo com o único argumento de que seu sistema carece de consistência. Quantos sistemas na história da filosofia são geralmente considerados totalmente consistentes ou 'sustentáveis'? Os filósofos clássicos são tidos em alta estima, não porque aceitamos e engolimos todo o sistema, mas principalmente por causa de intuições parciais e sugestões estimulantes. Visto sob essa luz, os próprios deméritos da filosofia de Bahnsen se tornam virtudes.

$\mathrm{Na}$ Realdialektik, possuímos um trabalho de profundo aperçu [panorama], de destemidas e perspicazes críticas, e uma discussão excitante sobre questões supremas. A filosofia também deve a Bahnsen a afirmação mais poderosa e irremovível antinomia objetiva da vida: a necessária oposição entre valor e existência ou o dualismo de valores da realidade. E o ponto em que o universo contém matéria e mente, necessidade e liberdade, lei e acaso, pode provar ser um fio de Ariadne através dos labirintos da discussão metafísica e da disputa de sistemas. E aqueles que suspeitam no amplo renascimento de Hegel hodierno, uma tentativa de obnubilar questões econômicas e intelectuais por uma 
teologia oculta descobrirão que suas presunções foram antecipadas em certa medida por Julius Bahnsen, ao lado de Karl Marx, o mais claro anti-hegeliano do século dezenove. Com exceção de Johannes Volkelt, nenhum pensador acadêmico tentou seriamente fazer justiça a Julius Bahnsen, o mais original dos seguidores de Schopenhauer. Está na hora de a filosofia acadêmica abrir suas portas para um sistema altamente interessante, mesmo que seus argumentos não sejam muito perpassados de urdidura lógica e encadeados, especialmente desde que as ideias diretrizes de dois filósofos contemporâneos notáveis tocam o problema fundamental de seu pensamento ${ }^{32}$.

\section{Referências}

BAHNSEN, Julius. Das Tragische als Weltgesetz und der Humor als ästhetische Gestalt des Metaphysischen: Monographien aus den Grenzgebieten der Realdialektik. Verlag nicht ermittelbar, 1877.

BAHNSEN, Julius Der Widerspruch im Wissen und Wesen der Welt: Princip und Einzelbewährung der Realdialektik. T. Grieben, 1882.

BAHNSEN, Julius Pessimisten-Brevier: Von einem Geweihten. Extractum vitae. Grieben, 1879.

BAHNSEN, Julius Wie ich wurde was ich ward. G. Müller, 1905.

KROHN, Rüdiger. Gottfried von Straßburg. Tristan. Bd, v. 3, 1980.

MAROLD, Karl et al. Gottfried von Strassburg: Tristan. E. Avenarius, 1906.

SCHOPENHAUER, Arthur. Arthur Schopenhauer's Sämtliche Werke. R. Piper \& Company, 1916.

SIMROCK, Karl et al. Das Nibelungenlied. Uebersetzt von Karl Simrock. Stuttgart, Cotta'schen Buchhandlung, 1868.

SLOCHOWER, Henry. Julius Bahnsen: Philosopher of Heroic Despair. The Philosophical Review, v. 41, n. 4, p. 368-384, 1932.

\footnotetext{
${ }^{32}$ A referência é à doutrina de Nicolai Hartmann sobre Aporien (Cf. seu Grundzüge einer Metaphysik der Erkenntnis (Linhas fundamentais para uma metafísica do conhecimento) e ao princípio de polaridade de Morris R. Cohen (Cf. Reason and Nature, New York, 1931).
} 